\section{Küçük Çocukların Sosyal-Duygusal Gelişiminin Desteklenmesinde Piramit Modeli}

\author{
Supporting Social-Emotional \\ Development of Young Children: Pyramid \\ Model
}

Turkish Journal of Special Education

Research and Practice

2021, Volume 3, Number 1, p 1-22 https://dergipark.org.tr/trsped

DOI: $10.37233 /$ TRSPED.2021.0110

Article History:

Received 28 January 2021

Revised 28 April 2021

Accepted 23 June 2021

Available online 15 December 2021

\begin{abstract}
Sinan Kalkan (101
Öz

Okul öncesi dönemde çocukların sosyal-duygusal gelişiminin desteklenmesi çocuklar için öğrenme, davranış ve sosyal kabul açısından kritik öneme sahiptir. Bu nedenle öğretmenler tarafından okul öncesi dönemdeki çocukların sosyal-duygusal gelişimlerinin desteklenmesi, çocukların gelişimi ve öğrenme süreçleri açısından oldukça önemlidir. Son yıllarda küçük çocukların sosyal-duygusal gelişimini ve öğrenme süreçlerini desteklemeye yönelik önleyici ve iyileştirici nitelikte, etkililiği araştırmalar tarafından kanıtlanmıș birçok strateji ve müdahale yaklașımı bulunmaktadır. Bu müdahale yaklaşımlarından biri de Piramit Modelidir. Bu çalışmada, okulöncesi yaş grubundaki çocukların sosyal-duygusal gelişimlerini desteklemek ve problem davranışlarını önlemek amacıyla geliştirilen önleyici müdahale programlarından biri olan Piramit Modelinin tanıtılması amaçlanmaktadır. Bu nedenle çalışmada, müfredat programlarıyla pedagojik açıdan uyumlu olan ve bu bağlamda işlevsellik gösteren Piramit Modelinin aşamaları tüm yönleriyle ele alınmaktadır. Piramit Modelinin tanıtılmasının ulusal alanyazında küçük çocukların sosyalduygusal gelişimlerini desteklemeyi hedefleyen erken çocukluk dönemi araştırmalarına yol göstereceği düşünülmektedir.
\end{abstract}

Anahtar Sözcükler: Piramit Modeli, sosyal-duygusal gelişim, problem davranış, erken müdahale.

\begin{abstract}
Supporting the social-emotional development of children in the preschool period is of critical importance for children in terms of learning, behavior, and social acceptance. For this reason, supporting the socialemotional development of preschool children by teachers is very important in terms of children's development and learning processes. In recent years, there are many preventative and remedial strategies and intervention approaches that have been proven by research to support the social-emotional development and learning processes of young children. One of these intervention approaches is the Pyramid Model. In this study, it is aimed to introduce the Pyramid Model, which is one of the preventive intervention programs developed to support the social-emotional development of children in the preschool age group and to prevent problem behaviors. For this reason, all aspects of the Pyramid Model, which is pedagogically compatible with the curriculum and functioning in this context, are discussed in this study. It is thought that the introduction of the Pyramid Model will guide early childhood studies that aim to support the social-emotional development of young children in the national literature.
\end{abstract}

Keywords: Pyramid Model, social-emotional development, problem behavioral, early intervention.

Önerilen Atıf Şekli (Suggested Citation): Kalkan, S. (2021). Küçük çocukların sosyal-duygusal gelişiminin desteklenmesinde Piramit Modeli. Turkish Journal of Special Education Research and Practice, 3 (1), 1-22.

https://doi.org/10.37233/TRSPED.2020.0110

${ }^{1}$ Çanakkale Onsekiz Mart Üniversitesi, Eğitim Fakültesi, Özel Eğitim Bölümü, Çanakkale, Türkiye, e-posta: $\underline{\text { sinan.kalkan@comu.edu.tr }}$ ORCID: https://orcid.org/0000-0001-6890-6421 


\section{Giriș}

Çocukların gelişiminde kritik bir dönem olan 0-8 yaş arasındaki erken çocukluk dönemi, gelişimin hem hızlı olduğu hem de çocukların yoğun düzeyde yetişkin desteğine gereksinim duyduğu bir dönemdir (Senemoğlu, 2018). Okul öncesi dönem, çocukların gelişim ve öğrenmelerine temel oluşturması nedeniyle bireyin yaşamı için belirleyici ve oldukça önemlidir. Bu dönemde çocukların bazıları tipik gelişim gösterirken, bazıları da etkilendikleri yetersizliklere veya gelişimlerini riske eden faktörlere bağlı olarak gelişimsel gerilik gösterebilmektedir. Erken çocukluk döneminde çocukların gelișimlerinin (a) bilișsel, (b) fiziksel, (c) motor ve (d) sosyal-duygusal gelișim olmak üzere dört gelişim alanı üzerinde şekillendiği gözlenmektedir (Senemoğlu, 2018). Sosyalduygusal gelişim alanı, diğer üç gelişim alanına temel oluşturmakla birlikte çocukların sosyal çevreye uyumunu kolaylaştırması, çocukların sosyal kabullerini sağlamada ana etken olarak görülmesi ve öğrenme süreçlerinin desteklenmesinde temel yapı olması nedeniyle oldukça önemli gelişim alanlarından biridir (Fox vd., 2011; Ostrosky ve Meadan, 2010). Okul öncesi dönemde çocukların sosyal-duygusal becerilerinin desteklenmesi ve gelişimi kritik öneme sahiptir. Sosyal-duygusal becerilerin desteklenmesi çocuğun içinde bulunduğu sosyal çevreye uyumunu kolaylaştırması ve sosyal kabulünü arttırması gibi çocuğa bu dönemde birçok avantaj sağlarken, çocuğun sosyal-duygusal becerilerindeki sinırlılıklar ya da yetersizlikler ile bunlara eşlik eden problem davranışlar ise çocuğa bu dönemde birçok yönden dezavantaj oluşturmaktadır (Günder, 2011; Hemmeter ve Conroy, 2018; Karaoğlu ve Ünüvar, 2017; Luo vd., 2017). Araștırmalar, çocukların sergilediği birçok problem davranışın temelinde sosyal becerilerdeki sinırlılıklar ya da yetersizlikler olduğunu ortaya koymaktadır (Fox vd., 2003; Gizir, 2002; Hemmeter vd., 2013).

Çocukluk döneminde sosyal-duygusal gelişiminde yetersizlik gösteren bireylerin, yetişkinlik döneminde hem içselleştirilmiş hem de dışsallaştırılmış problem davranışlar sergileme olasılıklarının daha fazla olduğu vurgulanmaktadır (Clegg ve Standen, 1991; Crick vd., 2006; Çelik vd., 2016; Schwartz vd., 2006). Bunun yanında araştırmalar, okul öncesi dönemde çocukların sosyal-duygusal gelişimiyle ilgili sınırlılık ve yetersizliklerine müdahale edilmediğinde, okul döneminde anti-sosyal davranışların artışında bir eğilim olduğunu (Davis vd., 2010; Davis vd., 2012; Diken vd., 2010) ve akademik becerilerde başarısızlık gözlemlendiğini de ortaya koymaktadır (Cristóvão vd., 2017; Rakap and Parlak-Rakap, 2011; Waltz, 2013; Zirpoli ve Melloy, 1997). Örneğin, Wright ve Steed (2021) Piramit Modelinin, kentsel dönüşlü bir ilköğretim okulundaki erken çocukluk sınıflarında uygulanmasını ele aldıkları araştırmada bir Piramit Modeli liderlik ekibi uygulamasının, (a) program düzeyinde, (b) öğretmenlerin Piramit Modeli uygulamalarını kullanması ve (c) çocukların sosyal duygusal sonuçları üzerinde katılımcılara sunulan eğitim ve uygulama temelli koçluğun etkilerini incelemiştir. Araştırmanın bulguları, katılımcılara sunulan eğitim ve uygulama temelli koçluk desteğinin küçük çocukların sosyal-duygusal gelişimlerini pozitif yönde etkilediğini göstermekle birlikte çocuklarda sosyal-duygusal gelişimin çocukların akademik başarılarında da belirleyici olduğunu göstermektedir. Benzer şekilde Rashid (2009) tarafından yürütülen bir başka araştırmada da erken sosyal-duygusal yeterliliğe odaklanan okul reformu çabalarının, çocukların akademik sonuçlarını iyileştirebileceğine ve okulda uzun vadeli başarı için zemin hazırlayabileceğine vurgu yapılmaktadır. Ek olarak araştırmalar, sosyal-duygusal gelişiminde yetersizlik gösteren çocukların, problem davranış sergileme açısından diğer çocuklara oranla daha fazla risk altında olabileceğini belirtmektedir (Hemmeter vd., 2015; Özyürek, 2015; Walker vd., 1995). 
Araştırmalar, erken çocukluk döneminde gelişmeye başlayan birçok sosyal-duygusal becerinin (örn., dinleme, takip etme, tepkide bulunma, yönergeleri yerine getirme, başkalarına duyarlı olma, düşünce ve duygular hakkında sözlü olarak iletişim kurma) okula hazır oluş açısından kazanılması gereken önemli beceriler olduğunu vurgulamaktadır (Kim vd., 2005; McClelland vd., 2017; O'Donnell, 2008). Piramit Modeli gibi kapsamlı çerçeve programların, küçük çocukların sosyal-duygusal gelişimini desteklemesinin ve problem davranışlarını önlemesinin yansıra okula yönelik hazırbulunuşluklarını destekleme noktasında da etkili programlar olduğu belirtilmektedir (Fox vd., 2010; Hemmeter vd., 2015). Bu nedenle çocuklar için gelişimsel açıdan belirleyici bir rolü olan sosyal-duygusal gelişim alanının desteklenmesi erken çocukluk döneminde bir zorunluluk olarak görülmeli ve bu süreç öğretmenler tarafından bilinçli bir şekilde planlanmalıdır (Kalkan ve Rakap, 2021).

Küçük çocukların sosyal-duygusal gelişimlerini desteklemek ve erken çocukluk eğitim ortamlarında sıklıkla çocuklar tarafından sergilenen problem davranışları önlemek/azaltmak amacıyla birçok ülkede önleyici ve iyileştirici müdahale programların geliștirilmesine ve uygulanmasına yönelik bir artış ve yaygın bir çabanın olmasına (Harkins, 2013) karşın küçük çocukların sosyal-duygusal gelişimlerini desteklemek ve problem davranışlarını önlemek amacıyla Piramit Modelinin kullanıldığı araştırma sayısı sinırlılık göstermektedir (Kalkan, 2019; Kalkan ve Rakap, 2021). Bu çalışmada okul öncesi dönemde çocukların sosyal-duygusal gelişimini destekleyen ve problem davranışlarını önlemede etkili olan çerçeve programlardan biri olan Piramit Modelinin tanıtılması amaçlanmıştır. Piramit Modeli gibi etkililiği bilimsel araştırmalarla kanıtlanmış çerçeve programların ülkemizde erken çocukluk eğitim ortamlarında kullanımının ve Piramit Modelini temel alan bilimsel araştırmaların yaygınlaştırılması açısından bu çalışmanın önemli bir işlev üstleneceği düşünülmektedir.

\section{Piramit Modelinin Kuramsal Çerçevesi}

Piramit Modeli, küçük çocukların sosyal duygusal yeterliliğini geliştirmek ve problem davranışlarını azaltmak için tasarlanmış evrensel, ikincil ve üçüncül aşamadan ve sistem desteklerinden oluşan bir çerçeve program olarak tanımlanmaktadır (Fox vd., 2003). Bu kavramsal çerçeve esasen kamu ve özel okul öncesi programları, kamu ve özel çocuk bakımı ve Head Start vb. erken çocukluk programları gibi Olumlu Davranışsal Müdahaleler ve Desteklerin (ODMD) çok katmanlı bir uygulamasını tanımlamaktadır (Dunlap ve Fox, 2015). Bir yaklaşım olarak Olumlu Davranış Desteği (ODD), 1980'lerin ortalarındaki başlangıcından bu yana birçok yönden gelişme göstermiştir (Lucyshyn vd., 2015). Başlangıçta ODD, ağır düzeyde gelişimsel yetersizliği olan bireylerin problem davranışlarını önlemek ve azaltmak amacıyla bir yaklaşım olarak geliştirilmiş ve gelişimini izleyen ilk 10 yıl boyunca ODD'nin tüm odak noktasını, problem davranışları olan bireylerin gereksinimleri oluşturmuştur.

Erken çocukluk bakımı ve eğitimine yönelik 1990’lı yıllardan itibaren yaygın bir çabanın olduğu gözlemlenmektedir. Özellikle, 1997 yılında Engelli Bireyler Eğitim Yasasinda (Individuals with Disabilities Education Act [IDEA]) ilk olarak ODMD desteklerinden söz edilmesiyle ve yapılan değişikliklerle birlikte bu çabanın desteklendiği söylenebilir. Bu bağlamda çok katmanlı kanıta dayalı destek sistemleri son yıllarda şaşırtıcı bir șekilde yaygınlaşmış ve hızla eğitsel, sosyal ve davranışsal müdahalelere yönelik kapsamlı yaklaşımlara temel oluşturmuştur (Fox vd., 2003; Sailor vd., 2009; Walker vd., 1996). ODD yaklaşımında, önemli düzeydeki problem davranışların ortaya çıkmasını önlemeye hizmet edebilecek müdahale uygulamalarına duyulan ihtiyacın artmasıyla birlikte büyük bir değişim de başlamıştır. Bu değişim, ODD’nin daha önce tüm 
yaklaşımı oluşturan nispeten yoğun ve bireyselleştirmeyi temel alan üçüncül uygulamalarına ek olarak evrensel ve ikincil uygulamaları içeren çok katmanlı sistemleri beraberinde getirmiştir (Walker vd., 1996; Sugai vd., 2000). Bu gelişmelerin büyük bir çoğunluğu, Olumlu Davranış Desteği (ODD) ve okul iklimini iyileştirmek (genel disiplini sağlamak ve okul ortamlarında problem davranışların oluşumunu önlemek) için kanıta dayalı uygulamaların bir kademesini kullanan Okul çapında Olumlu Davranış Desteği (OÇODD) çerçevesinde gerçekleşmiştir (Sailor vd., 2009).

Bu yaygın çabaların bir ürünü olarak 2003 yılında federal olarak finanse edilen bir grup araştırmacı ve program geliştirici tarafından, erken müdahale ve erken çocukluk programları (0-5 yaş arası) için "Piramit Modeli" adını verdikleri çok katmanlı bir model oluşturulmuştur (Fox vd., 2003). Piramit Modeli, Erken Öğrenmenin Sosyal ve Duygusal Temelleri Merkezi (CSEFEL) ve Sosyal Duygusal Müdahaleler Teknik Yardım Merkezi (TACSEI) olmak üzere iki ulusal merkez tarafından geliștirilmiştir. Bu iki merkez aracılığıyla, Piramit Modeli'nin erken çocukluk dönemi uygulayıcıları tarafından uygulanmasını desteklemek için bir mesleki gelişim yaklaşımı kullanılarak, 50 eyalette öğretmenler Piramit Modeli hakkında eğitim almış ve 5.000'den fazla eğitmen ve 2.500 koç eğitilmiştir (Hemmeter vd., 2014).

Piramit Modelinin temeli, esasen ODMD'den alınan kanıta dayalı prosedürlere ve çok küçük çocuklar için etkili müdahale yaklaşımları üzerine yapılan araştırmalara dayanmaktadır. Bu nedenle Piramit Modeli, modelin çok katmanlı çerçevesi ve ODMD ile yapısal benzerliklerinden dolayı Program Çapında Olumlu Davranış Desteği (PÇ-ODD) olarak adlandırılmıştır (Dunlap ve Fox, 2015). Özetle Piramit Modeli, önleme ve müdahale uygulamalarını temel alan halk sağlığı modelleri (Gordon, 1983; Simeonsson, 1991) ile okul çapında çok katmanlı olumlu davranış müdahale ve destek sistemlerinden (Horner vd., 2005; Walker vd., 1996) etkilenilerek geliştirilmiştir.

\section{Piramit Modeli}

Küçük çocukların sosyal-duygusal gelişimlerini desteklemeye yönelik önleyici ve iyileştirici özellikte etkililiği bilimsel araştırmalar tarafından kanıtlanmış birçok strateji, erken müdahale yaklaşımı ve Piramit Modeli gibi çerçeve program bulunmaktadır (Dunlap vd., 2006; Harkins, 2013; Ocak ve Arda, 2014). Piramit Modeli, küçük çocukların sosyal ve duygusal gelişimini desteklemeyi ve problem davranışlarını önlemeyi amaçlayan bilimsel dayanaklı bir modeldir. Piramit Modeli, modelde yer alan bilimsel dayanaklı uygulamaların üç aşamalı (dört farklı düzey) bir şekilde sunulmasını öngören kavramsal bir çerçeve sunmaktadır (Adams, 2012; Fox vd., 2003; Harkins, 2013; Heinze, 2013; Hemmeter vd., 2013). Model, evrensel destek aşaması, ikincil önleme aşaması ve üçüncül müdahale aşaması olmak üzere birbirini takip eden üç aşama ile evrensel destek aşamasından önce etkili işgücünü oluşturmaya yönelik birincil düzey de dahil olmak üzere dört farklı düzeyden oluşmaktadır. Buna göre modelin birinci düzeyi, etkili iş gücünü oluşturmaya yönelik olup ikinci düzeyi, destekleyici ilişkilere ve yüksek kaliteli çevresel desteklere odaklanırken üçüncü düzeyi, hedeflenen sosyal-duygusal desteği kapsamakta ve dördüncü düzeyi ise yoğun müdahalelerin gerçekleștirildiği bireyselleştirilmiş müdahalelerden oluşan destek ve stratejileri içermektedir (Center on the Social Emotional Foundations for Early Learning [CSEFEL], 2018; Fox vd., 2011; Hemmeter vd., 2006; Meadan ve Jegatheesan, 2010; Ostrosky ve Meadan, 2010; TACSEI, 2018). Piramit Modeli, okul öncesi öğretmenlerinin modelde yer alan farklı düzeylerdeki stratejileri kullanarak, okul öncesi dönemdeki çocukların sosyal-duygusal gelişimlerini desteklemelerine ve problem davranışlarını önlemelerine yardımcı olmak için tasarlanmıştır. 
Okul öncesi dönemde mesleki gelişim konusunda son yıllarda yürütülen birçok araştırma, okul öncesi öğretmenlerinin Piramit Modeli gibi etkili ve bilimsel dayanağı olan çok bileşenli çerçeve programları sınıflarında sistematik ve yaygın bir şekilde uygulamakta zorlandıklarını ya da çok az tercih ettiklerini ortaya koymaktadır (ArtmanMeeker vd., 2014; DiGennaro vd., 2007; Kretlow ve Bartholomew, 2010; Kretlow ve Blatz, 2011; Rakap vd., 2018; Kalkan ve Rakap, 2021; Trivette vd., 2012). Yapılan araştırmalar, öğretmenlerin sınıf içi uygulamalarını desteklemek ve etkili stratejileri sistematik bir şekilde kullanmalarını sağlamak için uygulama desteğine gereksinim duyduklarını ortaya koymaktadır (Eurydice Türkiye Birimi, 2009; Fox vd., 2011; Hemmeter vd., 2016; Rakap, 2016; Rakap vd., 2018). Bunun yanında araştırmalar erken çocukluk döneminde gelişmeye başlayan ve çocukların gelişimi için çok önemli olan dinleme, takip etme, tepkide bulunma, yönergeleri yerine getirme, başkalarına duyarlı olma, sözlü iletişim, başkalarının duygu ve düşüncelerini anlama ve onlara uygun tepkide bulunma gibi sosyal-duygusal becerilerin okula hazır olma açısından kazanılması gereken önemli beceriler olduğunu vurgulamaktadır (Kim vd., 2005; McClelland vd., 2017; O'Donnell, 2008; Strain ve Timm, 2001). Bu bağlamda, küçük çocukların sosyal-duygusal gelişimini destekleme, problem davranışlarını önleme ve okula hazırbulunuşluk becerileri için kapsamlı önleyici ve iyileștirici özellikte olan programlar, etkili programlar olarak düşünülmektedir (Fox vd., 2010; Hemmeter vd., 2015). Bu nedenle, çocukların sosyalduygusal becerilerini geliştirmek ve okul öncesi ortamlarda problem davranışlarını azaltmak amacıyla birçok ülkede önleyici ve iyileştirici müdahale programların geliştirilmesi ve uygulanmasına yönelik yaygın bir çabanın olduğu görülmektedir (Harkins, 2013). Bu yaygın çabaların bir ürünü olarak ortaya çıkan programlardan biri de "Piramit Modeli"dir (Fox ve Hemmeter, 2009; Hemmeter vd., 2006). Piramit Modeli'nin ortaya çıktığı 2000'li yılların başından bu yana, okul öncesi öğretmenleri ve sınıflarındaki çocuklar ile yürütülen, modelin tamamının ya da model içerisinde yer alan bazı stratejilerin etkililiğini inceleyen birçok araştırma gerçekleştirilmiştir (Artman-Meeker ve Hemmeter, 2013; Fettig ve Artman-Meeker, 2016; Fox vd., 2011; Hemmeter vd., 2015; Hemmeter vd., 2016; Lam ve Wong, 2017).

Hemmeter vd. (2016), öğretmenlerin sınıf içinde kullandıkları Piramit Modeli stratejilerinin, çocukların sosyal-duygusal becerileri ve problem davranışları üzerindeki etkilerini inceledikleri araştırmada, deney grubundaki öğretmenlerin, kontrol grubundaki öğretmenlere göre Piramit Modeli stratejilerini doğru kullanmada daha büyük bir gelişme gösterdiklerini ortaya koymuştur. Deney grubundaki öğretmenlerin sınıflarındaki çocukların kontrol grubundaki öğretmenlerin sınıflarındaki çocuklara göre sosyal etkileșim becerilerinin gelişimi ve problem davranışların azalmasında daha büyük gelişme gösterdikleri bulunmuştur. Fettig ve Artman-Meeker (2016), grup koçluk desteğinin okul öncesi öğretmenlerinin Piramit Modeli stratejilerini doğru ve sık kullanmaları üzerindeki etkilerini inceledikleri araştırmada, eğitime katılan ve grup koçluğu alan öğretmenlerin Piramit Modeli stratejilerini doğru kullanma düzeylerinde ortalama olarak \%20 civarında bir artış olduğunu göstermiştir. Bu bağlamda, öğretmenler öntest sırasında stratejileri \%43 oranında doğru bir şekilde uygularken sontest sırasında bu oran \%62'ye kadar çıkmıştır. Lam ve Wong (2017), küçük çocuklarda sosyal-duygusal gelișimi desteklemek amacıyla Piramit Modeli temel alınarak geliştirilen bir öğretmen eğitim programının anasınıflarına devam eden ve eğitime katılan öğretmenlerin sınıflarında yer alan çocukların sosyal beceri ve problem davranışları üzerindeki etkilerini inceledikleri çalışmada, öğretmenlere verilen eğitim ile birlikte çocukların sosyal-duygusal gelişimlerinde istatistiksel olarak anlamlı bir iyileşme olduğu ve müdahaleden sonra çocukların kaygı düzeyleri ile saldırgan davranışlarında önemli bir 
azalma olduğu görülmüştür. Fox vd., (2011) eğitim, uygulama rehberleri, sınıf materyalleri ile koçluk desteği içeren ve Piramit Modeli stratejilerinin öğretilmesine odaklı çok bileșenli bir mesleki gelişim programının, öğretmenlerin Piramit Modeli stratejilerini uygulama performansları üzerindeki etkilerini inceledikleri araştırmada, eğitim ve koçluk desteğini içeren mesleki gelişim programının, öğretmenlerin Piramit Modeli stratejilerini doğru bir şekilde kullanmaları üzerinde etkili olduğu görülmüş olup kalıcılık verisi toplanan ilk iki öğretmenin, Piramit Modeli stratejilerini bağımsız bir şekilde uygulamaya devam ettikleri rapor edilmiştir. Artman-Meeker ve Hemmeter (2013), tarafından Piramit Modeli kapsamında yer alan geçiş hazırlıkları, sınıf kurallarının öğretilmesi ve sosyal-duygusal becerilerin öğretimi ile ilgili stratejileri öğretmeyi amaçlayan ve performans geribildirimi içeren, bir hizmet içi eğitim programının okul öncesi öğretmenlerinin sınıf-içi uygulamaları üzerindeki etkilerinin incelendiği bu araştırmada, eğitim ile birlikte e-posta yoluyla sunulan performans geribildiriminin öğretmenlerin Piramit Modeli kapsamında yer alan stratejileri kullanmaları üzerinde etkili olduğunu ortaya koymuştur. Hemmeter vd., (2015) öğretmenlerinin sınıflarında Piramit Modeli stratejilerini uygulama düzeyleri üzerindeki etkilerini inceledikleri araştırmada, uygulanan mesleki gelişim programının öğretmenlerin Piramit Modeli stratejilerini öğrenmeleri ve uygulamaları üzerinde etkili olduğunu, üç katılımcının da öğrendikleri uygulamaları sürdürdüklerini ve bazı etkinliklere genellediklerini göstermiştir. Ek olarak, üç öğretmenden ikisinin sınıfında yer alan çocukların problem davranışlarında önemli düzeyde bir azalmanın olduğu görülmüştür.

$\mathrm{Bu}$ çalışmalar, Piramit Modelinin ve modelde yer alan stratejilerin okul öncesi öğretmenleri tarafından doğru bir şekilde ve sıklıkla kullanılması durumunda, okul öncesi dönemdeki çocukların sosyal-duygusal gelişimini desteklemede ve problem davranışlarını önlemede etkili bir yaklaşım olduğunu ortaya koymaktadır (Rakap vd., 2018). Piramit Modeli, tüm çocuklara sosyal-duygusal destek sağlamayı amaçlamakta ve bu amaca ulaşmak için okul öncesi öğretmenlerinin sınıflarındaki çocukların sosyalduygusal gelişimini destekleyici ve problem davranışlarını önleyici stratejileri, sınıf içi uygulamalarıyla bütünleştirmelerini gerektirmektedir. Bu yönüyle Piramit Modeli okul öncesi öğretmenlerinin takip ettiği müfredat ile kolaylıkla entegre olabilmektedir.

Piramit Modelinin sınıfın dinamik yapısı, çocukların ve öğretmenin ihtiyaçları bağlamında uyarlanarak müfredat uygulamaları için oluşturduğu çerçeve (Hemmeter vd., 2013), modelin pedagojik açıdan daha fazla uyumlu olmasını sağlamaktadır (Hemmeter vd., 2015). Piramit Modelinin spesifik olarak küçük çocukların sosyal-duygusal gelişimini desteklemeye ve problem davranışlarını önlemeye odaklanmış olması, onu diğer çerçeve programlardan ayıran en önemli özelliğidir (Fox vd., 2011; Hemmeter vd., 2017; Meadan ve Jegatheesan, 2010; Ostrosky ve Meadan, 2010). Piramit Modelinde yer alan önleyici stratejiler, problem davranışların ortaya çıkma olasılıklarıyla ilgili üç varsayıma dayanmaktadır. Buna göre, (a) çocukların gelişimsel özelliklerine uygun materyal ve etkinlik belirlenmediğinde, (b) çocuklar eğitim ortamı ve etkinliklerde ne yapacaklarını bilmediklerinde ve öğretmenin davranıș beklentilerini anlamadıklarında ve (c) gelișimsel açıdan uygun ve etkili iletişim becerilerine sahip olmadıklarında daha sık davranış problemleri sergiledikleri düşünülmektedir (Hemmeter vd., 2006).

\section{Piramit Modelinin Aşamaları}

Öğrenme Piramidi olarak da bilinen Piramit Modeli, üç aşamanın yer aldığı dört farklı düzeyden oluşmaktadır. Piramitte yer alan aşamalar genelden özele doğru "Evrensel Destek, Íkincil Önleme ve Üçüncül Müdahale" aşamalarıdır. Bu aşamalar Şekil 1'de 
gösterilmiştir. Piramit Modelinin birinci düzeyi etkili işgücünün oluşturulmasını hedeflemektedir. Etkili işgücünün oluşturulması, ebeveynler, meslektaşlar ve ilgili kuruluşlar ile ișbirliğini gerektirdiği gibi yerel kaynaklara erişimini ve bu kaynakların etkili kullanımını, ayrıca çocuklara yapılan müdahalelerde ve öğrenme süreçlerinin tamamında bilimsel dayanaklı uygulamaların kullanımını gerektirmektedir. Öğrenme Piramidi kapsamında yer alan aşamaların başarılı bir şekilde uygulanması, aşamaların birbirini desteklemesi ve bu aşamalarda yer alan uygulama ve stratejilerin hedeflenen çocuk davranışları üzerinde etkili olabilmesi, evrensel destek aşamasından önce gelen ve modelin birinci düzeyi olan etkili iş gücünün oluşturulmasıyla yakından ilișkilidir. Modelin birinci düzeyinde oluşturulan güçlü etkili iş gücü, aynı zamanda modelin diğer aşamalarındaki düzeylere temel oluşturmaktadır.

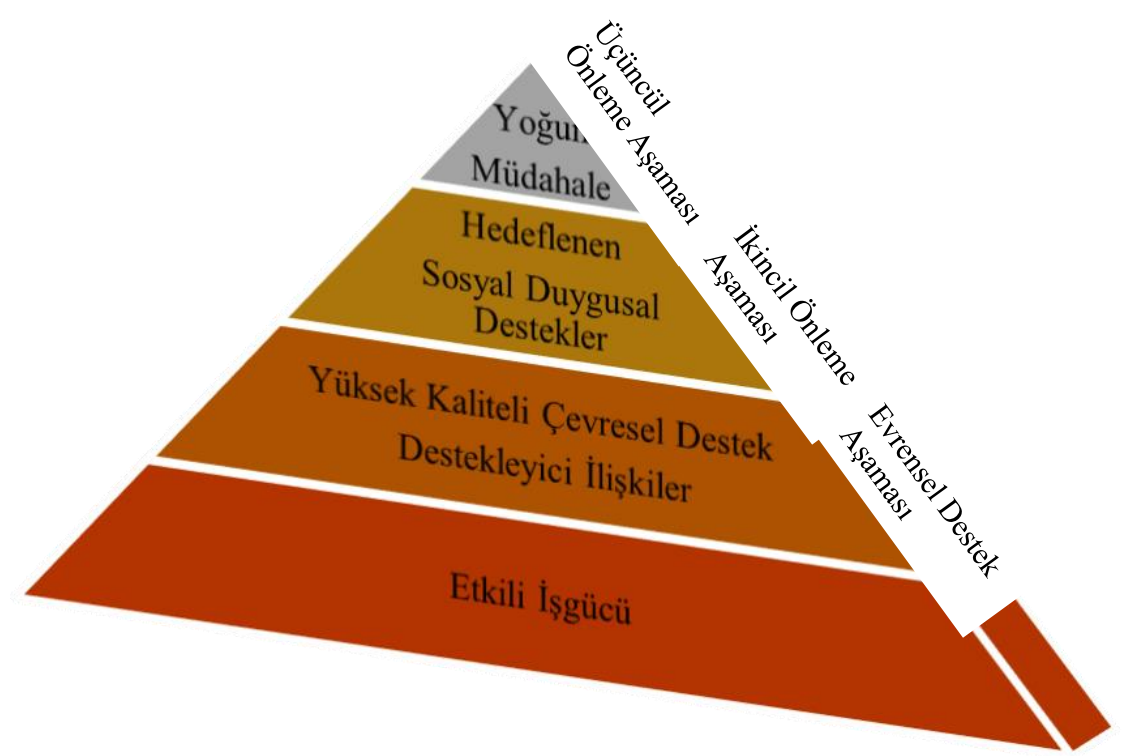

Şekil 1. Sosyal-duygusal öğrenme piramidi (Kaynak. Fox, L., Dunlap, G., Hemmeter, M. L., Joseph, G. E., \& Strain, P. S. (2003). The teaching pyramid: A model for supporting social competence and preventing challenging behavior in young children. Young Children, 58, 48-52.)

Etkili iş gücü temelinde bütün çocukları kapsayan Piramit Modeli'nin birincil evrensel destek aşaması, destekleyici ilişkiler ve yüksek kaliteli çevresel desteklerden oluşmaktadır. Bu aşamada, çocuklar ile çocuklara bakım sağlayan yetişkinler (öğretmen, ebeveyn ve bakıcı gibi) arasında olumlu ilișkilerin geliştirilmesi yoluyla sosyal-duygusal gelişimi destekleyici yüksek kaliteli ortamlar tasarlanmaktadır. Modelin üçüncü düzeyi olan ikincil önleme aşaması, hedeflenen sosyal-duygusal destekler ve öğretim stratejilerinden oluşmaktadır. İkincil önleme aşaması, açık bir şekilde sosyal becerilerin doğrudan öğretimine gereksinim duyan ve birincil evrensel destek aşamasındaki düzenlemelere ve müdahalelere rağmen, sosyal-duygusal gelişimi yetersiz olan ve problem davranışları devam eden çocukları hedef almaktadır. Üçüncül müdahale aşamasında ise ciddi düzeyde davranış problemleri ve sosyal beceri yetersizliği olan çocuklar için olumlu davranış destekli bireyselleştirilmiş yoğun müdahaleler söz konusudur (Fox vd., 2003; Hemmeter vd., 2013).

Piramidin evrensel destek aşaması, bu aşama sadece sosyal-duygusal gelişiminde sınırlılıklar olan ve problem davranış sergileyen çocukları değil, tüm çocukları kapsayacak uygulamaları içermektedir. Tüm çocukların sosyal-duygusal gelişiminin desteklenmesinin amaçlandığı bu aşama, (a) destekleyici ilişkiler ve (b) yüksek kaliteli çevresel destek olmak üzere iki düzeyden oluşmaktadır. Çocuklarda sosyal-duygusal 
gelişimin desteklenmesi ile buna bağlı becerilerin edinilmesi ve geliştirilmesinde güven temelli ilişkiler oldukça önemlidir. Güven temelli ilişkiler, çocukların çevrelerindeki kişilerin davranışlarını anlamalarına, nasıl tepki vereceklerini öğrenmelerine ve kendi davranışlarının çevreyi nasıl etkilediğini anlamalarına fırsat vermektedir (Altun-Könez, 2017; Fullerton vd., 2009; Lynch ve Simpson, 2010). Öğretmenler sinıflarındaki çocuklarla olumlu ilişkiler kurmak için jest, seçenek sunma (Lynch ve Simpson, 2010), beklentisinin ne olduğunu açlk bir şekilde belirtme (Algozzine vd., 2010), olumlu davranışları pekiştirme ve teşvik etme gibi çeşitli stratejiler kullanmaktadır (Meece ve Soderman, 2010). Bu bağlamda öğretmenlerin sınıflarındaki çocukları gülümseyerek selamlaması, aynı boy hizasında göz teması kurarak konuşması ve güven temelli iletişimi destekleyici dokunuşlarda bulunması, çocuklara önemli ve değerli olduklarını hissettirmek için kullanılabilecek basit stratejilerdendir. Ayrıca öğretmenler, çeşitli sorular sorarak çocukların ilgi alanlarını belirleyebilir ve ilgili alanları ile gelişimsel özelliklerine göre öğrenme merkezleri oluşturabilirler (Ostrosky ve Meadan, 2010).

Çocukların sosyal ve duygusal gelişimlerini desteklemek amacıyla uyarıcı, teşvik edici, katılımlarını arttırıcı, yüksek kaliteli ve destekleyici ortamlar gerekmektedir (AltunKönez, 2017; Dominguez vd., 2011; Lynch ve Simpson, 2010). Bu aşamada, öğretmenler çocukların öğrenme süreçlerini ve etkinliklere katılımını destekleyen çevresel düzenlemeler yaparlar; çocuklarla olumlu iletişime geçilir ve etkileşim kurulur; çocukların konuşma isteklerine olumlu karşılık verilir; çocukların uygun davranışları betimlenerek pekiştirilir ve davranışla ilgili olumlu geribildirimlerde bulunulur; çocukların akranları ve diğer yetişkinler ile destekleyici etkileşimler kurmaları teşvik eder (Fox vd., 2003; Hemmeter vd., 2008; Hemmeter ve Fox, 2009). Bu bağlamda evrensel destek aşaması güven temelli ilişkiler dışında, çocukları öğrenmeye teşvik eden yüksek kaliteli ortamları geliştirmeyi; sınıf kurallarını ve davranış beklentilerini öğretmeyi; etkinlikler ve ortamlar arası geçişleri yapılandırmayı; gün içerisinde gerçekleştirilecek etkinlik türleri (örn., öğretmen ve çocuk merkezli) arasında denge kurmayı; günlük etkinlik ve rutinleri belirlemeyi ve öğretmeyi destekleyen stratejileri içermektedir (AltunKönez, 2017; Lynch ve Simpson, 2010; Meadan ve Jegatheesan, 2010; Snyder vd., 2011)

Yüksek kaliteli çevresel destek öğrenme merkezlerinin düzenlenmesi ile materyal ve etkinliklerin belirlenmesinin dişında, sınıf içerisinde çocukların problem davranış sergileme olasılığını azaltmada etkili olan etkinlik çizelgeleri ve diğer destekleyici görsellerin geliştirilmesi ile kullanılmasını da kapsamaktadır. Yücesoy-Özkan'a (2013) göre çocukların günlük etkinlik programlarını tahmin etmesini kolaylaştırıcı görsellerin geliştirilmesi ve kullanılması, gün içerisinde gerçekleşen mevcut geçiş sayısının aza indirilmesi ve görsel hatırlatıcıların kullanılması gibi önleyici uygulamalar, tüm çocukların çevrelerini daha iyi anlamalarını, öğretmen beklentilerine uygun tepkiler geliştirmelerini ve doğal olarak problem davranışların daha az ortaya çıkmasını desteklemektedir. Tahmin edilebilirliği yüksek olan programlar, çocukların kendilerini rahat hissetmelerini sağlarken aynı zamanda etkinliklere katılımlarını da desteklemektedir. Bunula birlikte programın tutarlı ve tahmin edilebilir olması, çocukların kendilerini baskı altında hissetmemelerine ve katıldıkları sosyal oyunlarda daha uzun süre kalmalarına katkı sağlamaktadır (Epstein, 2009).

Piramit Modelinde yüksek kaliteli destekleyici bir ortam oluşturmak için kullanılan bir diğer strateji de öğretmenler tarafından geçişlerin etkili bir şekilde planlanmasıdır. Geçişler, çocukların bir etkinlikten diğerine geçmeleri sırasında ihtiyaç duydukları ve zamanında yerine getirilmesi gereken davranışları içermektedir. Geçişlerin planlaması, geçişler sırasında çocukların sergilediği problem davranışların azalmasına katkı sağlamaktadır (Lynch ve Simpson, 2010). Öğretmenler, etkinlikler arası geçişleri 
kolaylaştırma ve çocukların etkinliklere katılımlarını arttırabilmek amacıyla geçişleri, geçiş öncesi, geçiş sırası ve geçiş sonrası hazırlıkları ile düzenleyebilirler (Yücesoy-Özkan, 2013). Bu düzeyde yer verilmesi gereken stratejilerden biri de sinıf kurallarının oluşturulmasıdır (Pierce ve Johnson, 2010). Bu bağlamda sınıf kurallarının olumlu şekilde ifade edilmesi, sınıftaki tüm çocukların kendileri tarafından oluşturulan kurallara uymasını kolaylaștırmakla birlikte (Gartrell ve Gartrell, 2004), gün çerisinde belirlenen kuralların sık bir şekilde hatırlatılması ve kurallara uygun davranan çocukların pekiştirilmesi gerekmektedir. Öğretmenlerin yüksek kaliteli destekleyici bir sınıf ortamı oluştururken dikkate almaları gereken stratejilerden birisi de eğitim ortamının (öğrenme merkezleri ve diğer fiziki unsurlar) tasarlanmasıdır. Öğrenme merkezleri çocukların ilgi ve gereksinimleri dikkate alınarak hazırlanmalı ve çocukları gelişimsel açıdan destekleyecek nitelikte materyaller ile donatılmalıdır. Öğrenme merkezlerinin arasında sınırların belirgin olması, öğrenme merkezlerinde bulunması gereken çocuk sayısının belirlenmesi vb. uygulamalar çocukların öğrenme merkezlerinden etkili bir şekilde yararlanmalarına yardımcı olmaktadır (Altun-Könez, 2017; Ostrosky ve Meadan, 2010).

Piramidin ikincil önleme aşaması, Piramit Modelinin evrensel aşamasında sağlanan destekleyici olumlu ilişkilere ve yüksek kaliteli çevresel desteğe rağmen, sosyal-duygusal becerilerin geliştirilmesi bağlamında sorun yaşayan ve problem davranış göstermeye devam eden çocuklara küçük gruplar halinde sunulması hedeflenen sosyal-duygusal desteği içermektedir. Bu aşama, sosyal-duygusal gelişiminde gecikme riski olan çocuklara birinci aşamada sağlanan yapısal desteklerin yanında sosyal beceri, özdenetim, duygusal farkındalık geliştirme (duyguları anlama ve uygun tepkiden bulunma), arkadaşlık becerileri ve problem çözme konusunda küçük gruplar halinde öğretimin olduğu birçok farklı öğretim stratejisinden oluşmaktadır (Fox vd., 2011; Meadan ve Jegatheesan, 2010; Ostrosky ve Meadan, 2010).

Duyguları anlama ve ifade etme, sosyal-duygusal gelişim ve yeterlilik için hayati öneme sahiptir. Öğretmenler çocuklara duyguların nasıl tanımlanacağını ve ifade edilebileceğini doğrudan öğreterek (örn., model olarak, video izleterek, sosyal öyküler veya hikâye kitaplarından örnekler sunarak) çocukların, farklı duygu türlerini anlamalarına ve deneyimlemelerine katkı sağlayabilirler (Han ve Kemple, 2006). Bu aşamada sosyal-duygusal gelişimi destekleyici stratejilerden biri de çocuklara öfkelerini nasıl kontrol edebileceklerini öğretmektir. Bunun için dört adımdan (öfkelendiğini fark et, dur, kabuğuna çekil ve üç derin nefes al, problemin çözümünü düşün ve sakinleşince kabuğundan çık) oluşan kaplumbağa tekniği gibi farklı ve çocukların ilgisini çekecek teknikler kullanılabilir (TACSEI, 2018). Bu aşamada çocuklara öğretilen becerilerden biri de problem çözme becerileridir. Joseph ve Strain (2010), çocukların problem çözme becerilerindeki eksikliğinin saldırganlığa neden olduğunu ve bu durumun daha sonradan değiştirilmesinin güçleştiğini ifade etmektedir. Çocuklara problem çözme becerileri, (1) sorunun belirlenmesi, (2) birden fazla çözümün düşünülmesi, (3) her bir farklı çözümde ne olacağının düşünülmesi ve (4) bir çözümü seçip onun uygulanması olmak üzere dört adımda öğretilebilir (Fox vd., 2011; Joseph ve Strain, 2010; TACSEI, 2018). Problem çözme becerilerinin öğrenilmesi ve bu becerilerin uygulanması başlangıçta küçük çocuklar için zorlayıcı olabilir, ancak öğretmen model olarak ve gün içerisinde kendiliğinden ortaya çıkan doğal fırsatları kullanarak, çocukların bu zorlayıcı durumun üstesinden gelmelerini destekleyebilir.

Piramidin üçüncül müdahale aşaması, birincil evrensel destek ve ikincil önleme aşamalarında gerçekleştirilen müdahalelere cevap vermeyen çocuklar için bireyselleștirilmiş kapsamlı yoğun müdahalelerin gerçekleştirildiği aşamadır. Bu yoğun müdahaleler, süreğenliği olan problem davranışlara ve sosyal-duygusal becerilerde 
yüksek düzeyde sınırlılık/yetersizlik gösteren çocuklar için tasarlanmıştır (Altun Könez, 2017; Fox vd., 2011). Hemmeter ve diğerleri (2006), okul öncesi sınıflarındaki çocukların \%5-33'ünün daha yoğun müdahaleler gerektiren ve önemli düzeyde davranış problemlerine sahip çocuklar olduklarını ifade etmektedir. Bu aşamada yoğun desteğe gereksinim duyan (ağır düzeyde problem davranış sergileyen ve sosyal-duygusal yönden önemli düzeyde yetersizlik gösteren) çocuklar için sosyal-duygusal yetkinliklere yönelik eğitim, bireysel olarak daha belirgin bir şekilde sunularak çocuktaki ilerlemeler daha sık takip edilir (Altun Könez, 2017; Fox vd., 2010; Fox vd., 2011). Üçüncül müdahale aşamasında, bireyselleștirilmiş müdahale sunulan çocuklar için evrensel ve ikincil önleme aşamasındaki destekler aynen devam ettirilir. Özetle, Öğrenme Piramidinin üçüncül müdahale aşaması, problem davranışların ortaya çıkmasını azaltmaya yönelik önleyici stratejilerin birlikte kullanımı ile problem davranışların ortadan kaldırılması (iyileștirici) için bireyselleştirilmiş yoğun müdahaleleri gerektirmektedir (Snyder vd., 2011). Bu bağlamda, çocuk için çocuk ile etkileşim halinde olan birden fazla uzmanın katılımı ile olumlu davranış destek planları geliştirilebilir. Bu planlar kapsamında ele alınan stratejiler müdahale edilmesi düşünülen davranıșın işlevsel olarak değerlendirilmesiyle belirlenir (Dunlap ve Fox, 2011).

\section{Piramit Modeli Uygulamalarının/Stratejilerinin Değerlendirilmesi}

Piramit Modeli, küçük çocukların sosyal-duygusal gelişimini desteklemek ve problem davranışları önlemek amacıyla deneysel olarak desteklenen öğretim uygulamalarını düzenleyen çok katmanlı bir çerçeve programdır. Piramit Modelinin ilk aşaması, besleyici ve duyarlı ilişkiler ve yüksek kaliteli destekleyici sınıf ortamları ile ilgili evrensel uygulamaları vurgulamakta olup ikinci aşaması, açık sosyal-duygusal ve davranışsal öğretim uygulamalarına; modelin üçüncü aşaması ise bireyselleştirilmiş davranış destek planlarının geliştirilmesiyle sonuçlanan değerlendirmeye dayalı bir sürece odaklanmaktadır. Piramit Modeli uygulamalarını değerlendirilmesinde birçok değerlendirme aracı kullanılmakla birlikte (örn., Focal Child Observation System; Social Skills Improvement System Rating Scale) esasen temel değerlendirme aracı olarak, Piramit Modeli uygulamalarını ve stratejilerini değerlendirmek amacıyla yine Piramit Modelinin geliştiricilerinin içinde bulunduğu bir gurup (Hemmeter vd., 2008) tarafından hazırlanan Okul Öncesi Sınıflar için Öğretim Piramidi Gözlem Aracı (The Teaching Pyramid Observation Tool [TPOT]) kullanılmaktadır.

Okul Öncesi Sinıflar için Öğretim Piramidi Gözlem Aracı (The Teaching Pyramid Observation Tool [TPOT]; Hemmeter vd., 2008): öğretmenlerin Piramit Modelinin her bir bileşeniyle ilgili uygulamaları gerçekleştirirken, Piramit Modeli uygulama ve stratejilerinin doğru kullanımını ölçmek amacıyla geliştirilmiş bir araçtır. Bu bağlamda öğretmenlerin Piramit Modeli öğretim uygulamalarını ve uygulama tutarlılı̆̆ını ölçmek için nesnel bir yol sağlamak için geliştirildiği söylenebilir (Hemmeter vd., 2014). TPOT, yaklaşık 2 saatlik bir gözlem ve gözlem sonrasında öğretmenlerle 15 ila 20 dakikalık bir görüşme yapılarak uygulanır. TPOT, alt ölçekler olarak düzenlenmiş üç bölümden oluşmaktadır. Birinci alt ölçekte, Piramit Modeli çerçeve çalışmasından türetilen 14 temel uygulama/strateji maddesi bulunmaktadır: (1) programlar, rutinler ve faaliyetler; (2) faaliyetler arasında geçişler; (3) destekleyici konuşmalar; (4) çocukların katılımını teşvik etmek; (5) yönerge vermek; (6) işbirliğine dayalı ekip oluşturma; (7) davranış beklentilerini öğretmek; (8) sosyal becerileri ve duygusal yeterlilikleri öğretmek; (9) arkadaşlık becerilerini öğretmek; (10) çocuklara duyguları ifade etmeyi öğretmek; (11) problem çözmeyi öğretmek; (12) kalıcı problem davranışları olan çocuklar için müdahaleler; (13) ailelerle iletişim kurmak ve (14) Piramit Modeli uygulamalarının aile 
kullanımını desteklemek. Her bir uygulama/strateji ile ilişkili uygulama göstergelerinin sayısı 5 ila 10 arasında değişmektedir. TPOT'ın bu bölümünde $(14$ temel uygulama/strateji) toplam 114 uygulama/strateji göstergesi bulunmaktadır. TPOT'ın ikinci alt ölçeği 17 kırmızı işareti içermektedir. Kırmızı işaretler, Piramid Modeli uygulamalarıyla çelișen veya bunları engelleyen, sınıf ortamında zayıf yapısal ve etkileşimsel kalitenin göstergeleridir. Piramit Modeli uygulamalarının/stratejilerinin aslına uygun olarak uygulanmasına bağlı olarak herhangi bir kırmızı işaretin görülmemesi beklenmektedir. TPOT'ın üçüncü alt ölçeği, problem davranışlara müdahale etmek için etkili stratejileri kullanmaya odaklanmaktadır. Bu alt ölçek, okul öncesi sınıflarda problem davranışlara müdahalede bulunmak için öğretmenlerin kullanması gereken üç temel uygulamayı içermektedir. TPOT'ın bu kısmı yalnızca bir TPOT gözlemi sırasında problem davranışlar ortaya çıktığında kullanılmaktadır.

TPOT'ın psikometrik özellikleri, potansiyel uygulamaların bir parçası olmayan 50 okul öncesi sınıfı üzerinde incelenmiştir (Snyder vd., 2013). Buna göre genelleştirilebilirlik analizlerinden elde edilen sonuçlar, olaylara ve değerlendiricilere atfedilen minimum hata varyansının \%1'den az olduğunu göstermiș olup G katsayısının, olaylara ve değerlendiricilere göre ortalama .94 olduğunu ortaya koymuștur. Yakınsak puan geçerliliği ile ilgili olarak, Sınıf Değerlendirme Puanlama Sistemi (CLASS; Pianta vd., 2008) için toplam TPOT temel uygulama puanları ile bileşik alan puanları arasındaki Pearson çarpım-moment korelasyon katsayıları duygusal destek için .70, sınıf organizasyonu için .73 ve öğretim desteği için .76 olarak hesaplanmıştır (Hemmeter vd., 2014). TPOT ile ilgili yürütülen çalışmalar, bu gözlem sisteminin uygun psikometrik özelliklere sahip olduğunu göstermektedir. Bu bağlamda, ölçeğin iç tutarlılık değerleri alt ölçekler için .35 ile .82 arasında değişirken, değerlendiriciler arası güvenirlik katsayısı \%89 ve üzeri olarak bulunmuştur (Fox vd., 2014; Rakap vd., 2018).

\section{Piramit Modelinin Mesleki Gelişim Üzerine Etkileri}

Erken çocukluk döneminin çocukların gelişimi üzerindeki belirleyici ve kritik etkisi dikkate alındığında, bu dönemde küçük çocuklarla çalışan öğretmenlerin rollerinin ve bu bağlamda mesleki donanımları ile sınıf içi uygulamalarının önem kazandığı söylenebilir. Öğretmenlerin sınıf içi uygulamalarının iyileştirilmesinde ve geliştirilmesinde önemli bağlamlardan biri de mesleki gelişimlerinin desteklenmesidir. $\mathrm{Bu}$ doğrultuda öğretmenlerin mesleki becerilerinin geliştirilmesinde önemli süreçlerden biri olan mesleki gelişimi, mesleğin icra edilmesinde gerekli olan işlevsel mesleki bilgi ve beceriler ile mesleki haklara ilişkin edinimin, mesleğin icra edildiği ortamlarda uygulanmasını desteklemek üzere tasarlanmış eğitim ve öğrenme deneyimleri olarak tanımlayabiliriz (National Professional Development Center on Inclusion [NPDCI], 2008).

Erken çocukluk dönemi öğretmenlerinin mesleki donanımları ile çocukların davranışları ve gelişimleri arasında olumlu bir ilişkinin olduğu vurgulanmaktadır (Bierman vd., 2008; Türk Eğitim Derneği, 2017). Bu nedenle, erken çocukluk döneminde küçük çocuklarla çalışan öğretmenlerin niteliklerini ve yeterliklerini geliştirmenin birincil öneme sahip olduğu belirtilmektedir (Brandon ve Martinez-Beck, 2006). Öğretmenlerin mesleki gelişimleri dünyanın birçok ülkesinde, hizmet öncesi (lisans eğitimi) ve hizmet içi (kurs, seminer, lisansüstü eğitim) olmak üzere iki şekilde desteklenmektedir (Kalkan, 2019). Ancak araştırmalar, öğretmenlerin gereksinimlerinin dikkate alınmadığı, genellikle bir ya da iki oturumdan oluşan mesleki gelişim faaliyetlerinin (kurs ve seminer ağırlıklı yürütülen), öğretmenlerin sınıf içi uygulamalarını iyileștirme ve geliştirmede sınırlı bir etkiye sahip olduğunu vurgulamaktadır (Arıkan vd., 2017; Snyder ve Wolfe, 2008). Son yıllarda, okul öncesi 
öğretmenlerinin hizmetiçi dönemde mesleki gelişimlerinin desteklenmesinde farklı mesleki gelişim modellerinin etkililiğini inceleyen araștırmalar, birden fazla oturumdan oluşan yüksek kaliteli çalıştaylara/seminerlere ek olarak, performans geribildirimine dayalı uygulama yardımı içeren mesleki gelişim faaliyetlerinin, öğretmenlerin sınıf içi uygulamalarını desteklemede daha etkili olduğunu ortaya koymuştur (örn., ArtmanMeeker ve Hemmeter, 2013; Fettig ve Artman-Meeker, 2016; Fox vd., 2011; Hemmeter vd., 2015; Hemmeter vd., 2016; Hemmeter vd., 2017; Kalkan, 2019; Lam ve Wong, 2017; Rakap, 2015; Snyder vd., 2012; Snyder vd., 2018).

Türkiye'de öğretmen yetiştirme programları ve gerçekleştirilen mesleki gelişim faaliyetleri incelendiğinde okul öncesi dönemde çocukların sosyal-duygusal gelişimlerinin desteklenmesine yönelik gerçekleştirilen mesleki gelişim faaliyetlerinin oldukça sınırlı olduğu (Kalkan, 2019); dahası Türkiye'de okul öncesi eğitim ortamlarında çalışan birçok öğretmenin, küçük çocukların sosyal-duygusal gelişimlerini desteklemeye ve problem davranışlarını önlemeye yönelik strateji ve uygulamaları bilmedikleri ya da uygulama becerisine sahip olmadıkları görülmektedir (Rakap vd., 2018). Alanyazında farklı mesleki gelişim modellerinin öğretmenlerin uygulama performansları üzerindeki etkisini inceleyen araştırmalar, birden fazla oturumdan oluşan yüksek kaliteli çalıștay ya da seminerlere ek olarak performans geribildirimi desteğinin verildiği uygulama yardımı içeren mesleki gelişim faaliyetlerinin, öğretmenlerin uygulama performansları üzerinde daha etkili olduğunu ortaya koymuştur (örn., Artman-Meeker ve Hemmeter, 2013; Fettig ve Artman-Meeker, 2016; Hemmeter vd., 2015; Hemmeter vd., 2016; Lam ve Wong, 2017; Rakap, 2015; Snyder vd., 2018; Sucuoğlu ve Bakkaloğlu, 2015). Bu bağlamda okul öncesi öğretmenlerin küçük çocukların sosyal-duygusal gelişimlerini desteklemeye yönelik ortaya çıkan mesleki gereksinimlerini (sınıf içi uygulamalarını iyileştirmek ve geliştirmek için) karşılamak amacıyla birden fazla çalıştay ya da seminere ek olarak uygulama desteği içeren etkili mesleki gelişim programlarına ihtiyaç duyulmaktadır (Kalkan ve Rakap, 2021).

Okul öncesi öğretmenlerinin ortaya çlkan mesleki gereksinimlerinin karşılanmasında uygulama desteği içeren etkili çerçeve programlardan birinin de Piramit Modeli olduğu söylenebilir. Okul öncesi öğretmenlerinin mesleki gelişimlerinin desteklenmesine odaklanan ve Piramit Modeli uygulama ve stratejilerinin öğretimini temel alan araştırmaların, mesleki gelişim faaliyetlerinin birden fazla oturumdan oluşan çalıştay ya da seminere ek olarak sınıf içi gözlem ve yerinde müdahaleyi içeren (koçluk) uygulama desteği sunduğu görülmektedir (Kalkan, 2019). Alanyazında Piramit Modeli uygulamalarının/stratejilerinin öğretimini temel alan mesleki gelişim faaliyetleri incelendiğinde birden fazla çalıștaya ek olarak 8-16 arasında değişen koçluk desteğinin sunulduğu görülmekle birlikte (örn., Artman-Meeker ve Hemmeter, 2013; Fox vd., 2011; Hemmeter vd., 2015; Hemmeter vd., 2016; Kalkan, 2019; Lam ve Wong, 2017) koçluk desteğinin genellikle son çalıştayı takiben sunulduğu gözlenmektedir. Ayrıca araştırmalarda uygulama temelli koçluğun, planlama, gözlem ve geribildirim olmak üzere üç temel süreçte sunulduğu ve koçluk desteğinin genellikle iki saatlik sınıf içinde öğretmen uygulamalarının gözlenmesi ve akabinde 15-20 dakikalık görüşmeler şeklinde gerçekleştiği görülmektedir. Bu bağlamda Piramit Modeli uygulama ve stratejilerinin öğretimini temel alan araştırmaların sonuçları, okul öncesi öğretmenlerinin Piramit Modelinin stratejilerini yüksek oranda öğrendiklerini ve sınıf içerisinde başarılı bir şekilde uyguladıklarını, dahası stratejilerin öğretmenler tarafından başarılı bir şekilde uygulanmasının çocukların sosyal-duygusal gelişimlerini desteklediğini ve problem davranışlarını azalttığını göstermektedir (Kalkan ve Rakap, 2021). 


\section{Sonuç}

$\mathrm{Bu}$ çalışmada, okul öncesi dönemdeki çocukların sosyal-duygusal gelişimlerini desteklemek ve problem davranışlarını önlemek üzere geliştirilen önleyici ve iyileştirici niteliğe sahip çerçeve programlardan biri olan Piramit Modelinin tanıtılması amaçlanmıştır. Piramit Modeli, okul öncesi dönemdeki çocukların sosyal-duygusal gelişimlerini desteklemek ve problem davranışlarını önlemek amacıyla ABD'de okul öncesi öğretmenleri için geliştirilmiş, etkililiği bilimsel araştırmalarla kanıtlanmış bilimsel dayanaklı bir çerçeve programdır. Piramit Modelinin her bir aşaması, kendinden önceki aşama ya da düzeyi birlikte uygulamayı gerektirmekle birlikte modelin öğretmen uygulamaları ve çocuk çıktıları üzerindeki etkisinin başarısı aşamaların birlikte uygulanmasına bağlıdır. Son zamanlarda gerek uluslararası (örn., Luo vd., 2017) gerekse ülkemizde (örn., Kalkan, 2019) doğrudan Piramit Modeli ya da Piramit Modeli temelli yapılan çalışmaların sayısında bir artış olduğu gözlemlenmektedir. Yapılan araştırmalar, Piramit Modelinin okul öncesi yaş grubundaki çocukların sosyal-duygusal gelişimini desteklediği ve problem davranışlarını önlediğini ortaya koymakla birlikte, modelin okul öncesi öğretmenlerinin mesleki performanslarını iyileștirmede diğer bir deyişle mesleki gelişimlerini desteklemede etkili olduğu görülmektedir (Kalkan ve Rakap, 2021). Bu nedenle Piramit Modeli uygulamalarının/stratejilerinin öğretimini temel alan ve koçluk gibi uygulama desteği içeren mesleki gelişim faaliyetlerinin yaygınlaştırılmasına ve bu konuda daha fazla araştırma yapılmasına gereksinim bulunmaktadır.

\section{Kaynakça}

Adams, J. M. (2012). Assessing the effectiveness of individualized behavior support interventions for children with challenging behavior in early care and education settings (Unpublished doctoral dissertation). Vanderbilt University.

Algozzine, B., Horner, R. H., Sugai, G., Barrett, S., Dickey, S. R., Eber, L., \& Tobin, T. (2010). Evaluation blueprint for school-wide positive behavior support. National Technical Assistance Center on Positive Behavior Interventions and Support. www.pbis.org/evaluation/evaluation blueprint.aspx

Altun-Könez, N. (2017). Olumlu davranış destekleri: Sorunlu davranışların yönetimi ve önlenmesi. H. Bakkaloğlu \& B. Sucuoğlu (Çev. Ed.). Okulöncesinde bütünleştirmeyi hayata geçirme (ss.195-218) içinde. Nobel Akademik Yayıncılık.

Arıkan, A., Fernie, D. E., \& Kantor, R. (2017). Supporting the professional development of early childhood teachers in head start: A case of acquiring technology proficiency. Illköğretim Online, 16(4), 1829-1849. http://doi.org/10.17051/ilkonline.2017.342996

Artman-Meeker, K. M., \& Hemmeter, M. L. (2013). Effects of training and feedback on teachers' use of classroom preventive practices. Topics in Early Childhood Special Education, 33(2), 112-123. https://doi.org/10.1177/0271121412447115

Artman-Meeker, K., Hemmeter, M. L., \& Snyder, P. (2014). Effects of distance coaching on teachers' use of pyramid model practices: A pilot study. Infants \& Young Children, 27(4), 325-344. http://doi.org/10.1097/IYC.0000000000000016

Bierman, K. L., Domitrovich, C. E., Nix, R. L., Gest, S. D., Welsh, J. A., Greenberg, M. T., \& Gill, S. (2008). Promoting academic and social-emotional school readiness: The head start REDI program. Child Development, 79(6), 1802-1817. https://doi.org/10.1111/i.1467-8624.2008.01227.x 
Brandon, R. N. and Martinez-Beck, I. (2006). Estimating the size and characteristics of the United States early care and education workforce. In M. Zaslow \& I. Martinez-Beck (Eds.), Critical issues in early childhood professional development (pp. 4976). Brookes.

Center on the Social and Emotional Foundations for Early Learning. (2018). Pyramid Model for supporting social emotional competence in infants and young children. http://www.gunnison.colostate.edu/ecc/ecc docs/csefel.pdf

Clegg, J. A., \& Standen, P. J. (1991). Friendship among adults who have developmental disabilities. American Journal on Mental Retardation, 95(6), 663-671.

Crick, N. R., Ostrov, J. M., \& Werner, N. E. (2006). A longitudinal study of relational aggression, physical aggression, and children's social-psychological adjustment. Journal of Abnormal Child Psychology, 34(2), 127-138. http://doi.org/10.1007/s10802-005-9009-4

Cristóvão, A. M., Candeias, A. A., \& Verdasca, J. (2017). Social and emotional learning and academic achievement in Portuguese schools: A bibliometric study. Frontiers in Psychology, 8, 1-12. https://doi.org/10.3389/fpsyg.2017.01913

Çelik, S., Arikan, A., Diken, I. H., Aksoy, F., Çolak, A., \& Tomris, G. (2016). Effectiveness of the Preschool Version of the First Step to Success Early Intervention Program for preventing antisocial behaviors. Educational Sciences: Theory and Practice, 16(2), 511-535. https://doi.org/10.12738/estp.2016.2.0317

Davis, E., Priest, N., Davies, B., Sims, M., Harrison, L., Herrman, H. \& Cook, K. (2010). Promoting children's social and emotional wellbeing in childcare centers within low socioeconomic areas: Strategies, facilitators, and challenges. Australasian Journal of Early Childhood, 35(3), 1-16. https://doi.org/10.1177/183693911003500310

Davis, E., Young, D., Corr, L., \& Cook, K. (2012). Organizational capacity building in childcare: Promoting children's mental health. International Journal of Mental Health Promotion, 14(5), 264-275. https://doi.org/10.1080/14623730.2013.784595

DiGennaro, F. D., Martens, B. K., \& Kleinmann, A. E. (2007). A comparison of performance feedback procedures on teachers' treatment implementation integrity and students' inappropriate behavior in special education classrooms. Journal of Applied Behavior Analysis, 40(3), 447-461. https://doi.org/10.1901/jaba.2007.40-447

Diken, İ. H., Cavkaytar, A., Batu, S., Bozkurt, F., \& Kurtyılmaz, Y. (2010). Proje ADYEP: Anasınıfı, ilköğretim birinci ve ikinci sınıflarında anti sosyal davranışları önlemeye yönelik bir erken müdahale programının etkililiği (Proje No: 206K165). Türkiye Bilimsel ve Teknolojik Araştırma Kurumu.

Domínguez, X., Vitiello, V. E., Fuccillo, J. M., Greenfield, D. B., \& Bulotsky-Shearer, R. J. (2011). The role of context in preschool learning: A multilevel examination of the contribution of context-specific problem behaviors and classroom process quality to low-income children's approaches to learning. Journal of School Psychology, 49(2), 175-195. https://doi.org/10.1016/j.jsp.2010.11.002

Dunlap, G., \& Fox, L. (2015). The Pyramid Model: PBS in early childhood programs and its relation to school-wide PBS. Pyramid Model Consortium. https://challengingbehavior.cbcs.usf.edu/docs/Pyramid-Model PBS-earlychildhood-programs Schoolwide-PBS.pdf 
Dunlap, G., Strain, P. S., Fox, L., Carta, J. J., Conroy, M., Smith, B., \& Sowell, C. (2006). Prevention and intervention with young children's challenging behavior: A summary and perspective regarding current knowledge. Behavioral Disorders, 32(1), 29-45. https://doi.org/10.1177/019874290603200103

Epstein, A. S. (2009). Me, you, us: Social-emotional learning in preschool. High/Scope.

Eurydice Türkiye Birimi. (2009). Avrupa'da erken çocukluk eğitimi ve bakımı: Sosyal ve kültürel eşitsizliklerle ilgilenmek. Du ve Se Ajans.

Fettig, A., \& Artman-Meeker, K. (2016). Group coaching on pre-school teachers' implementation of Pyramid Model strategies: A program description. Topics in Early $\begin{array}{llll}\text { Childhood Special } & \text { Education, }\end{array}$ https://doi.org/10.1177/0271121416650049

Fox, L., \& Hemmeter, M. L. (2009). A program-wide model for supporting social emotional development and addressing challenging behavior in early childhood settings. In W. Sailor, G. Dunlap, G. Sugai, \& R. Horner (Eds.), Handbook of positive behavior support (pp. 177-202). Springer.

Fox, L., Carta, J., Strain, P. S., Dunlap, G., \& Hemmeter, M. L. (2010). Response to intervention and the Pyramid Model. Infants \& Young Children, 23(1), 3-13. http://doi.org/10.1097/IYC.0b013e3181c816e2

Fox, L., Dunlap, G., Hemmeter, M. L., Joseph, G. E., \& Strain, P. S. (2003). The Teaching Pyramid: A model for supporting social competence and preventing challenging behavior in young children. Young Children, 58(4), 48-52.

Fox, L., Hemmeter, M. L., \& Jack, S. (2010). Early childhood program-wide PBS benchmarks of quality (Unpublished instrument). University of South Florida.

Fox, L., Hemmeter, M. L., Snyder, P., Binder, D. P., \& Clarke, S. (2011). Coaching early childhood special educators to implement a comprehensive model for promoting young children's social competence. Topics in Early Childhood Special Education, 31(3), 178-192. https://doi.org/10.1177/0271121411404440

Fullerton, E. K., Conroy, M. A., \& Correa, V. I. (2009). Early childhood teachers' use of specific praise statements with young children at risk for behavioral disorders. Behavioral Disorders, 34(3), 118-135. https://doi.org/10.1177/019874290903400302

Gartrell, D., \& Gartrell, D. (2004). The power of guidance: Teaching social-emotional skills in early childhood classrooms. Thomson/Delmar Learning.

Gizir, Z. (2002). Anaokuluna devam eden dört-beş yas çocuklarında sosyal davranışların gelişimi ile benlik saygısı arasında ilişsinin incelenmesi (Yayımlanmamış yüksek lisans tezi). Ankara Üniversitesi.

Gordon, R.S. (1983). An operational classification of disease prevention. Public Health Reports, 98, 107-109.

Günder, E. (2011, Eylül). Okul öncesi dönemde çocukların sosyal uyum becerilerinin değerlendirilmesi [Sözlü sunum]. 20. Eğitim Bilimleri Kurultayı, Mehmet Akif Ersoy Üniversitesi, Burdur. 
Han, H. S., \& Kemple, K. M. (2006). Components of social competence and strategies of support: Considering what to teach and how. Early Childhood Education Journal, 34(3), 241-246. https://doi.org/10.1007/s10643-006-0139-2

Harkins, D. M. (2013). Coaching in the context of social-emotional development: Implications for targeted early childhood professional development. University of California.

Heinze, L. K. (2013). Effects of puppet teaching strategies through social emotional teaching pyramid in an integrated preschool classroom (Unpublished doctoral dissertation). Southwest Minnesota State University.

Hemmeter, M. L., \& Conroy, M. A. (2018). Advancement of evidence-based programs for young children with social and emotional learning difficulties. School Mental Health, 10(3), 199-201. https://doi.org/10.1007/s12310-018-9275-2

Hemmeter, M. L., \& Fox, L. (2009). The Teaching Pyramid: A model for the implementation of classroom practices within a program-wide approach to behavior support. NHSA DIALOG, 12(2), 133-147. https://doi.org/10.1080/15240750902774718

Hemmeter, M. L., Fox, L., \& Snyder, P. (2008). Teaching Pyramid Observation ToolResearch Edition (Unpublished assessment instrument). Vanderbilt University.

Hemmeter, M. L., Fox, L., \& Snyder, P. (2014). Teaching Pyramid Observation ToolResearch Edition [Manual]. Brookes.

Hemmeter, M. L., Fox, L., \& Snyder, P., (2013). A tiered model for promoting socialemotional competence and addressing challenging behavior. In V. Buysse \& E. Peisner-Feinberg (Eds.), Handbook of response to intervention in early childhood (pp. 85-101). Brookes.

Hemmeter, M. L., Hardy, J. K., Schnitz, A. G., Adams, J. M., \& Kinder, K. A. (2015). Effects of training and coaching with performance feedback on teachers' use of Pyramid Model practices. Topics in Early Childhood Special Education, 35(3), 144-156. https://doi.org/10.1177/0271121415594924

Hemmeter, M. L., Ostrosky, M., \& Fox, L. (2006). Social and emotional foundations for early learning: A conceptual model for intervention. School Psychology Review, 35(4), 5816013. https://doi.org/10.1080/02796015.2006.12087963

Hemmeter, M. L., Snyder, P. A., Fox, L., \& Algina, J. (2016). Evaluating the implementation of the Pyramid Model for promoting social-emotional competence in early childhood classrooms. Topics in Early Childhood Special Education, 36(3), 133-146. https://doi.org/10.1177/0271121416653386

Hemmeter, M. L., Snyder, P., \& Fox, L. (2017). Using the Teaching Pyramid Observation Tool (TPOT) to support implementation of social-emotional teaching practices. School Mental Health, 10(3), 202-213. https://doi.org/10.1007/s12310-017-9239-y

Horner, R. H., Sugai, G., Todd, A. W., \& Lewis-Palmer, T. (2005). School-wide positive behavior support. In L. Bambara \& L. Kern (Eds.). Individualized supports for students with problem behavior: Designing positive behavior plans. (pp. 359-390). Guilford Press.

Joseph, G., \& Strain, P. S. (2010). Teaching young children interpersonal problem-solving skills. Young Exceptional Children, 13(3), 28-40. https://doi.org/10.1177/1096250610365144 
Kalkan, S. (2019). Sosyal-duygusal gelişimi risk altında olan okul öncesi çocuklarına yönelik piramit modeline dayalı uygulama temelli koçluk desteği içeren öğretmen mesleki gelişim programının etkililiği (Yayımlanmamış doktora tezi). Gazi Üniversitesi.

Kalkan, S. \& Rakap, S. (2021). Okul öncesi dönemde sosyal-duygusal gelişimin desteklenmesi: Piramit Modeli ile ilgili çalışmaların gözden geçirilmesi ve ayrıntılı bibliyografisi. Yaşadıkça Eğitim, 311-332. https://doi.org/10.33308/26674874.2021352280

Karaoğlu, H., \& Ünüvar, P. (2017). Okul öncesi dönem çocuklarının gelişim özellikleri ve sosyal beceri düzeyleri. Mehmet Akif Ersoy Üniversitesi Eğitim Fakültesi Dergisi, (43), 231-254.

Kim, J., Murdock, T., \& Choi, D. (2005). Investigation of parents' beliefs about readiness for kindergarten: An examination of National Household Education Survey (NHES: 93). Educational Research Quarterly, 29(2), 3-17.

Kretlow, A. G., \& Bartholomew, C. C. (2010). Using coaching to improve the fidelity of evidence-based practices: A review of studies. Teacher Education and Special Education, 33, 279-299. https://doi.org/10.1177/0888406410371643

Kretlow, A. G., \& Blatz, S. L. (2011). The ABCs of evidence-based practice for teachers. $\begin{array}{llll}\text { Teaching Exceptional } & \text { 8hildren, }\end{array}$ https://doi.org/10.1177/004005991104300501

Lam, L. T., \& Wong, E. M. (2017). Enhancing social-emotional well-being in young children through improving teachers' social-emotional competence and curriculum design in Hong Kong. International Journal of Child Care and Education Policy, 11(15), 51-14. https://doi.org/10.1186/s40723-017-0031-0

Lucyshyn, J.M., Dunlap, G., \& Freeman, R. (2015). A historical perspective on the evolution of positive behavior support as a science-based discipline. In F. Brown, J. Anderson, \& R. DePry (Eds.), Individual positive behavior supports: A standards-based guide to practices in school and community-based settings (pp. 3-25). Paul H. Brookes Publishing.

Luo, L., Snyder, P., Clark, C. L., \& Hong, X. (2017). Preschool teachers' use of Pyramid Model practices in Mainland China. Infants \& Young Children, 30(3), 221-237. https://doi.org/10.1097/IYC.0000000000000096

Lynch, S. A., \& Simpson, C. G. (2010). Social skills: Laying the foundation for success. Dimensions of Early Childhood, 38(2), 3-12.

McClelland, M. M., Tominey, S. L., Schmitt, S. A., \& Duncan, R. (2017). SEL interventions in early childhood. The Future of Children, 27(1), 33-47.

Meadan, H., \& Jegatheesan, B. (2010). Classroom pets and young children. YC Young Children, 65(3), 70-77.

Meece, D., \& Soderman, A. K. (2010). Positive verbal environments: Setting the stage for young children's social development. Young Children, 65(5), 81-86.

National Professional Development Center on Inclusion. (2008). What do we mean by professional development in the early childhood field? https://npdci.fpg.unc.edu/sites/npdci.fpg.unc.edu/files/resources/NPDCI Professio nalDevelopmentInEC 03-04-08 0.pdf 
O'Donnell, C. L. (2008). Defining, conceptualizing, and measuring fidelity of implementation and its relationship to outcomes in $\mathrm{K}-12$ curriculum intervention research. Review of Educational Research, 78(1), 33-84. https://doi.org/10.3102/0034654307313793

Ocak, Ş., \& Arda, T. B. (2014). Okul öncesi dönemde önleyici müdahale edici programların karşılaştırılması. Hacettepe Üniversitesi Eğitim Fakültesi Dergisi, 29(4), 171-188.

Ostrosky, M. M., \& Meadan, H. (2010). Helping children play and learn together. YC Young Children, 65(1), 104-110.

Özyürek, A. (2015). Okul öncesi çocukların sosyal beceri düzeyleri ile anne tutumları arasındaki ilişkinin incelenmesi. Milli Eğitim Dergisi, 106-120.

Pianta, R.C., La Paro, K.M., \& Hamre, B.K. (2008). Classroom assessment scoring system manual: Pre-K. Paul H. Brookes Publishing.

Pierce, J., \& Johnson, C. L. (2010). Problem solving with young children using persona dolls. Young Children, 65(6), 106-108.

Rakap, S. (2016). Özel eğitimde bilimsel dayanaklı uygulamalar. Aksoy, V. (Ed.), Özel eğitim (ss. 181-211) içinde. Pegem Akademi.

Rakap, S., \& Parlak-Rakap, A. (2011). Effectiveness of embedded instruction in early childhood special education: A literature review. European Early Childhood Education Research Journal, 19(1), 79-96. https://doi.org/10.1080/1350293X.2011.548946

Rakap, S., Balikci, S., Kalkan, S., \& Aydin, B. (2018). Preschool teachers' use of strategies to support social-emotional competence in young children. International Journal of Early Childhood Special Education, 10(1), 11-25. http://doi.org/10.20489/intjecse.454103

Rashid, H. M. (2009). From brilliant baby to child placed at risk: The perilous path of African American boys in early childhood education. The Journal of Negro Education, $7(3), 347-358$.

Sailor, W., Dunlap, G., Sugai, G., \& Horner, R. (2009) (Eds). Handbook of positive behavior support. Springer.

Schwartz, D., Gorman, A. H., Nakamoto, J., \& McKay, T. (2006). Popularity, social acceptance, and aggression in adolescent peer groups: Links with academic performance and school attendance. Developmental Psychology, 42(6), 1116-1127. https://doi.org/10.1037/0012-1649.42.6.1116

Senemoğlu, N. (2018). Gelişim, öğrenme ve öğretim: Kuramdan uygulamaya (25. baskı). Anı Yayıncılık.

Simeonsson, R.J. (1991). Primary, secondary, and tertiary prevention in early intervention. Journal of Early Intervention, 15, 124-134.

Snyder, P. A., Hemmeter, M. L., Fox, L., Bishop, C. C., \& Miller, M. D. (2013). Developing and gathering psychometric evidence for a fidelity instrument: The Teaching Pyramid Observation Tool-Pilot Version. Journal of Early Intervention, 35(2), 150-172.

Snyder, P., \& Wolfe, B. (2008). The big three process components of effective professional development: Needs assessment, evaluation, and follow-up. In P. J. Winton, J. A. McCollum, \& C. Catlett (Eds.), Practical approaches to early childhood professional development: Evidence, strategies, and resources (pp. 13-52.). Zero to Three. 
Snyder, P., Hemmeter, M. L., Artman, K., Kinder, K., Pasia, C., \& McLaughlin, T. (2012). Characterizing key features of the early childhood professional development literature. Infants and Young Children, 25, 188-212.

Snyder, P., Hemmeter, M. L., McLean, M., Sandall, S., McLaughlin, T., \& Algina, J. (2018). Effects of professional development on preschool teachers' use of embedded instruction practices. Exceptional Children, 84(2), 213-232.

Snyder, P., McLaughlin, T., \& Denney, M. (2011). Frameworks for guiding program focus and practices in early intervention. In J. M. Kauffman \& D. P. Hallahan (Series Ed.) \& M. Conroy (Section Ed.), Handbook of special education: Section XII Early identification and intervention in exceptionality (pp. 716-730). Routledge.

Strain, P. S., \& Timm, M. A. (2001). Remediation and prevention of aggression: An evaluation of the Regional Intervention Program over a quarter century. Behavioral Disorders, 26(4), 297-313. https://doi.org/10.1177/019874290102600409

Sucuoğlu, B., \& Bakkaloğlu, H. (2015). Okul öncesinde kaynaştırma: Öğretmen eğitimi. Pegem Akademi.

Sugai, G., Horner, R.H., Dunlap, G., Hieneman, M., Lewis, T.J., Nelson, C.M., Scott, T., Liaupsin, C., Sailor, W., Turnbull, A.P., Turnbull, H.R. III, Wickham, D., Ruef, M., \& Wilcox, B. (2000). Applying positive behavior support and functional behavioral assessment in schools. Journal of Positive Behavior Interventions, 2, 131-143.

Technical Assistance Center on Social Emotional Intervention for Young Children. (2018). Creating teaching tools for young children with challenging behaviors: Folder fourturtle

technique. http://challengingbehavior.cbcs.usf.edu/TACSEI/do/resources/teaching tools/ttyc toc.htm

Trivette, C. M., Raab, M., \& Dunst, C. J. (2012). An evidence-based approach to professional development in Head Start classrooms. NHSA Dialog, 15(1), 41-58. https://doi.org/10.1080/15240754.2011.636489

Türk Eğitim Derneği. (2017). Türkiye'de erken çocukluk eğitimi ve bakımı: Mevcut durum ve öneriler. https://tedmem.org/download/turkiyede-erken-cocukluk-egitimibakimi-mevcut-durum-oneriler?wpdmdl $=2430$

Walker, H. M., Horner, R. H., Sugai, G., Bullis, M., Sprague, J., Bricker, D., \& Kaufman, M. J. (1996). Integrated approaches to preventing antisocial behavior patterns among school age children and youth. Journal of Emotional and Behavioral Disorders, 4, 194209.

Walker, H. M., Severson, H. H., \& Feil, E. G. (1995). Early screening project manual. Sopris West.

Waltz, M. (2013). The importance of social and emotional development in young children. https://childrensacademyonline.net/wpcontent/uploads/2013/01/ImportanceofSEL-In-Early-Childhood-Devt.pdf

Wright, J. D., \& Steed, E. A. (2021). Implementing the Pyramid Model in a turnaround elementary school. Preventing School Failure: Alternative Education for Children and Youth, 1-9. https://doi.org/10.1080/1045988X.2021.1898320

Yücesoy-Özkan, Ş. (2013). Okul öncesi sınıflarında sınıf yönetimi ve problem davranışların kontrolü. B. Sucuoğlu \& H. Bakkaloğlu (Eds.), Okul öncesinde 
kaynaştırma: Ne, ne zaman, nerede, neden, nasıl, kim? (ss. 191-260) içinde. Kök Yayıncılık.

Zirpoli, T., \& Melloy, K. (1997). Behavior management: Applications for teachers and partners (2nd edition). Prentice Hall.

\section{Extended Summary}

\section{Supporting Social-Emotional Development of Young Children: Pyramid Model}

\section{Introduction}

It is observed that the development of children in early childhood is shaped on four developmental areas: (a) cognitive, (b) physical, (c) motor and (d) social-emotional development (Senemoğlu, 2018). The social-emotional development area is one of the most important areas of development as it facilitates the adaptation of children to the social environment, is seen as the main factor in ensuring children's social acceptance and is a basic structure in supporting learning processes (Fox et al., 2011; Ostrosky and Meadan, 2010). While supporting social-emotional skills provides the child with many advantages in this period, such as facilitating the child's adaptation to the social environment and increasing social acceptance, the limitations or inadequacies in the child's social-emotional skills and the problem behaviors accompanying them create a disadvantage for the child in this period (Günder, 2011; Hemmeter and Conroy, 2018; Karaoğlu and Ünüvar, 2017; Luo et al., 2017). Studies reveal that the limitations or insufficiencies in social skills are the basis of many problem behaviors displayed by children (Fox et al., 2003; Gizir, 2002; Hemmeter et al., 2013). For this reason, supporting the social-emotional development area, which has a developmentally determining role for children, should be seen as a necessity in early childhood and this process should be planned consciously by teachers. In this study, it was aimed to introduce the Pyramid Model, one of the intervention programs that support the social-emotional development of children in the preschool period and are effective in preventing problem behaviors.

\section{Pyramid Model}

The Pyramid Model is a scientifically based model that aims to support the social and emotional development of young children and prevent problem behaviors. The Pyramid Model is a conceptual framework that envisages the presentation of the scientific-based applications in the model in three stages (four different levels) (Adams, 2012; Fox et al., 2003; Harkins, 2013; Heinze, 2013; Hemmeter et al., 2013). The Pyramid Model is designed to help preschool teachers support the social-emotional development of preschool children and prevent problem behaviors by using the strategies at different levels included in the model. The model consists of four different levels: primary universal support stage, secondary prevention stage and tertiary intervention stage. Accordingly, the first level of the model is towards creating an effective workforce; the second level focuses on supportive relationships and high quality environmental supports; the third level includes targeted social-emotional support; The fourth level includes support and strategies consisting of individualized interventions where intensive interventions are 
carried out (Center on the Social Emotional Foundations for Early Learning [CSEFEL], 2018; Fox et al., 2011; Hemmeter et al., 2006; Meadan and Jegatheesan, 2010; Ostrosky and Meadan, 2010; TACSEI, 2018b).

The Pyramid Model is adapted to the dynamic structure of the classroom, the needs of children and teachers, and the framework created for curriculum applications (Hemmeter, Fox, and Snyder, 2013) ensures that the model is more pedagogically compatible (Hemmeter et al., 2015). The most important feature of the Pyramid Model that distinguishes it from other framework programs is that it is specifically focused on supporting the social-emotional development of young children and preventing problem behaviors (Fox et al., 2011; Hemmeter et al., 2017; Meadan and Jegathean, 2010; Ostrosky and Meadan, 2010).

\section{Phases of the Pyramid Model}

The Pyramid Model, also known as the Learning Pyramid, consists of three stages and four different levels. The stages in the pyramid are the stages of Primary Universal Support, Secondary Prevention and Tertiary Intervention from general to specific. The successful implementation of the stages within the scope of the Learning Pyramid and the support of the stages are closely related to the creation of an effective workforce, which is the first level of the model.

The primary universal support phase of the pyramid includes practices that will cover all children, not just children with problem behaviors. This stage consists of two levels: (a) supportive relationships and (b) high quality environmental support. The secondary prevention phase of the pyramid includes the aim of providing small groups of social-emotional support to children who have problems in the context of the development of social-emotional skills and continue to display problem behavior, despite the supportive positive relationships and high-quality environmental support provided in the universal stage of the Pyramid Model. The tertiary intervention phase of the pyramid is the phase where individualized comprehensive intensive interventions are carried out for children who do not respond to the interventions performed in the primary universal support and secondary prevention phases. These intense interventions are designed for children who show chronic problem behaviors and high-level limitations/disabilities in social-emotional skills (Altun-Könez, 2017; Fox et al., 2011). At this stage, for children who need intense support (who exhibit severe problem behaviors and have significant social-emotional insufficiency), education for social-emotional competencies is offered more specifically individually, and progress in the child is followed more frequently (Altun-Könez, 2017; Fox et al., 2010; Fox et al., 2011). In the tertiary intervention phase, universal and secondary prevention support for children with individualized intervention is continued.

\section{Result}

In this study, it is aimed to introduce the Pyramid Model, which is one of the preventive intervention programs developed to support the social-emotional development of preschool children and prevent problem behaviors. The Pyramid Model is a scientificallybased preventive intervention program that has been developed for preschool teachers in the USA to support the social-emotional development of preschool children and prevent problem behaviors, and its effectiveness has been proven by scientific research. Although each stage of the Pyramid Model requires applying the previous stage or level 
together, the success of the model depends on the application of the stages together. Recently, it has been observed that there has been an increase in the number of studies carried out directly based on the Pyramid Model or Pyramid Model both in our international and in our country (e.g., Kalkan, 2019). Studies have shown that the Pyramid Model supports the social-emotional development of children in the preschool age group and prevents problem behaviors, but it is seen that the model is effective in improving the professional performance of preschool teachers, in other words, supporting their professional development.

\section{Yazar(lar)in Beyanı}

Araştırmacıların katkı oranı beyanı: Araştırmacılar çalışmaya eşit oranda katkı yapmışlardır.

Etik Kurul Kararı: Bu makalede sunulan çalışmanın bir derleme çalışması olması nedeniyle etik kurul iznine gerek duyulmamaktadır.

Çatışma beyanı: Araştırmada yazarlar arasında ya da diğer kişi/kurum/kuruluşlarla herhangi bir çıkar çatışması bulunmamaktadır.

Destek ve teşekkür: $\mathrm{Bu}$ araştırma için herhangi bir kurumdan finansal destek alınmamıştır. 